\title{
ANALISIS KESALAHAN PENGGUNAAN KATA BAKU PADA TEKS LAPORAN HASIL OBSERVASI SISWA KELAS X MAN 2 MODEL MEDANTAHUN PEMBELAJARAN 2016/2017
}

\section{Oleh}

\section{Sri Rahayuni Tanjung (srirahayuni90@gmail.com) Drs. Tangson R. Pangaribuan, M.Pd}

Kata baku adalah ragam bahasa yang cara pengucapan maupun penulisannya sesuai dengan kaidah - kaidah standar. Kaidah - kaidah standar ini dapat berupa pedoman ejaan, tata bahasa baku, dan kata kamus umum. Penelitian ini merupakan penelitian deskriptif kualitatif.Subjek penelitian ini adalah teks laporan hasil observasi yang ditulis siswa kelas $\mathrm{X}$ IPA2 MAN 2 Model Medan tahun pembelajaran 2016/2017. Objek penelitian ini adalah kalimat yang mengandung unsur kesalahan penggunaan kata baku. Metode penelitian yang digunakan adalah metode deskriptif kualitatif, yaitu mendeskripsikan suatu keadaan alamiah secara mendalam dan terperinci mengenai kesalahan penggunaan kata baku pada teks laporan hasil observasi siswa kelas $\mathrm{X}$ MAN 2 Model Medan. Untuk menemukan dan mengklasifikasikan kalimat yang mengandung kesalahan penggunaan kata bakudigunakan teknik membaca, mencermati fokus dan konteks, dan mencatat. Instrumen pada penelitian ini adalah penulis sendiri (human instrument), yaitu sebagai instrumen kunci dengan menggunakan bantuan tabel analisis kesalahan kata baku.Hasil penelitian kesalahan penggunaan kata baku pada teks laporan hasil observasi siswa kelas X MAN 2 Model Medan, yaitu (1) Kesalahan penggantian huruf sebanyak 70 (19,1\%)kesalahan, 23 teks dikategorikan sangat baik, 16 teks dikategorikan baik, dan 4 teks dikategorikan cukup.(2) Kesalahan penghilangan huruf sebanyak 46 (12,6\%)kesalahan, 31 teks dikategorikan sangat baik, 8 teks dikategorikan baik, dan 2 teks dikategorikan cukup, dan 2 teks dikategorikan sangat kurang. (3) Kesalahanpenyederhanaan huruf sebanyak 23 (6,3\%) kesalahan, 27 teks dikategorikan sangat baik, 10 teks dikategorikan baik, dan 6 teks dikategorikan sangat kurang. (4) Kesalahanejaan sebanyak 226 (62\%) kesalahan, 25 teks dikategorikan sangat baik, 14 teks dikategorikan baik, 3 teks dikategorikan cukup dan 1 teks dikategorikan kurang. (5) Kesalahan pilihan kata sebanyak 14 (3.7\%) kesalahan, 33 teks dikategorikan sangat baik, 8 teks dikategorikan kurang, dan 2 teks dikategorikan sangat kurang.

\author{
Kata Kunci :AnalisisKesalahan, Kata Baku, Penggunaan huruf, Ejaan, Pilihan \\ Kata
}

\section{PENDAHULUAN}

Salah satu cara yang bisa dilakukan seseorang untuk bisa berbahasa dengan baik dan benar adalah memahami tentang kata baku dan kata tidak baku. Kemudian setelah memahami tentang kata baku lalu menerapkannya, baik dalam kegiatan berbahasa yang membutuhkan media lisan maupun media tulisan (Arifah \& Isnawati Nur, 2016 : 23).Dewasa ini 
penggunaan bahasa baku oleh masyarakat dan pelajar sangat rancu menempatkan kata dalam kalimat. Tentunya hal ini disadari atau tidak ketika penulisan kata maupun pemakaian huruf yang tidak sesuai dengan Pedoman Umum Ejaan Bahasa Indonesia (PUEBI). Oleh karena itu penggunaan kata baku menjadi salah satu materi esensial dalam pembelajaran bahasa Indonesia.

Berbicara tentang kesalahan berbahasa unsur ejaan, tentu tidak terlepas dari siswa sebagai peserta didik dalam proses pembelajaran. Dengan beragamnya bentuk kesalahan berbahasa siswa yang tidak sesuai dengan ejaan.Kemudian teks yang beredar pada saat ini, menuntut banyak keingintahuan siswa untuk menganalisis, mencermati, dan memahami tata bahasa.Ketika menulis atau berbicara, tentunya selalu menggunakan kata. Kata tersebut dibentuk menjadi kelompok kata, klausa, kalimat, paragraf, dan akhirnya sebuah wacana.Dalam belajar bahasa, siswa dapat mengembangkan kemampuannya untuk memahami dan memproduksi bahasa. Pengembangan tersebut meliputi belajar atau membiasakan penggunaan bahasa baku dalam berkomunikasi.

Kemampuan berbahasa siswa pada umumnya bervariasi, ada siswa yang memiliki kemampuan berbahasa yang baik dan ada siswa yang lemah kemampuan berbahasanya. Hal ini tentunya sesuai dengan perkembangan bahasanya belum sampai pada tingkat kebahasaan yang sesuai kaidah akan mengalami kesulitan dalam menulis. Adapun penyebab kegagalan siswa dalam belajar karena kurangnya pengetahuan bahasa baku yang digunakan dalam teks juga besarnya pengaruh bahasa sehari - hari (B1) atau bahasa asing.

Penulisan laporan hasil observasi ini berkaitan erat dengan ragam tulisan, karena menulis pada hakikatnya menyampaikan ide atau gagasan dengan menggunakan lambang grafis (tulisan). Menulis merupakan keterampilan bahasa yang sama pentingnya dari keterampilan yang lain seperti menyimak, membaca, dan berbicara. Dengan demikian kurangnya latihan menulis menjadi kendala siswa dalam merangkai suatu kata dan menuangkan apa yang adadalam isi kepalanya.

Berdasarkan hasil wawancara peneliti dengan guru bidang studi Bahasa Indonesia MAN 2 Model Medan menyatakan bahwa kemampuan siswa masih rendah dalam penggunaan kata baku. Ada sebanyak 18 orang atau sekitar $45 \%$ siswa yang lulus dengan nilai rata - rata 75 . Sedangkan sisanya 22 orang atau sekitar $55 \%$ tidak mencapai standar kompetensi yang telah ditentukan dari sekolah yaitu 75.Adapun kesalahan siswa, yaitu pada penggunaan huruf dan aspek ejaan.

Hal tersebut disebabkan oleh beberapa kendala, diantaranya : 1) kemampuan siswa masih rendah dalam penggunaan kata baku bahasa Indonesia, 2) kurangnya pengethuan siswa 
terhadap penggunaan kata baku bahasa Indonesia, 3) siswa kesulitan dalam menulis teks laporan hasil observasi siswa terpengaruh oleh bahasa ibu atau sehari - hari, 4) banyaknya kesalahan siswa terhadap penggunaan kata baku dalam tulisan siswa, 5) kurangnya perhatian siswa dalam memproduksi teks laporan hasil observasi.

Penelitian mengenai analisis penggunaan kata baku telah banyak dilakukan seperti yang dikemukakan olehMiftahudin (2014: 69)dalam skripsinya yang berjudul "Analisi Kesalahan Penggunaan Kata Baku dalam Pembelajaran Menulis Laporan Perjalanan Siswa Kelas VII SMP Al-Hidayah Lebak Bulus Jakarta." Ibu Misbah selaku guru bidang mata pelajaran B. Indonesia menyatakan bahwa kemampuan siswa masih rendah dalam penggunaan kata baku, hali ini terlihat dari hasil ujian mata pelajaran ejaan sesuai dengan kurikulum 2013 yang digunakan di MAN 2 Model Medan. Hal ini juga didukung olehWidianingsih (2014 : 108)dalam skripsinya yang berjudul "Analisis Kesalahan Ejaan pada Buku Teks Terbitan Yudhistira dan Erlangga." Adapun penggunaan bahasa baku oleh siswasangat rancu menempatkan kata dalam kalimat. Tentunya hal ini disadari atau tidak ketika penulisan kata maupun pemakaian huruf yang tidak sesuai dengan Pedoman Umum Ejaan Bahasa Indonesia (PUEBI).Guru mampu membantu mengatasi kesalahan siswa yang ditimbulkan oleh kesalahan penggunaan kata baku yang sesuai dengan kaidah dan aturan bahasa Indonesia.

Berdasarkan uraian yang telah dipaparkan, bahwa tujuan analisis kesalahan berbahasa secara tradisional sangat praktis, yaitu sebagai umpan balik demi kepentingan penyusunan materi pembelajaran bahasa. Berdasarkan uraian di atas, maka penulis mengambil judul penelitian “Analisis Kesalahan Penggunaan Kata Baku pada Teks Laporan Hasil Observasi Siswa Kelas X MAN 2 Model Medan Tahun Pembelajaran 2016/2017.”

\section{METODE PENELITIAN}

Metode penelitian adalah cara dalam proses pemecahan masalah dengan mengumpulkan dan menganalisis data. Metode penelitianjuga merupakan segala kegiatan yang dilakukan dalam sebuah penelitian dalam upaya menemukan dan membuktikan sesuatu sepenuhnya tergantung pada metode yang digunakan.

Metode penelitian kualitatif deskriptif yang dimaksudkan dapat memberi gambaran terntang fenomena apa yang dialami oleh subjek penelitian. Penelitian ini menggunakan pendekatan kualitatif. Pengkajian pada penelitian ini dilakukan secara mendalam dan terperinci guna memperoleh suatu deskripsi yang jelas terhadap kesalahan penggunaan kata baku pada penggantian huruf, penghilangan huruf, penyederhanaan huruf, dan ejaan dalam 
teks laporan hasil observasi.Sudaryanto (2015:15), mengatakan "Metode kualitatif adalah metode penelitian yang semata - matahanya berdasarkan fakta yang ada atau fenomena yang memang secara empiris hidup pada penutur - penuturnyasehingga yang dihasilkan atau dicatat berupa data yang apa adanya".

Pengumpulan data yang dihasilkan dari penelitian bukanlah angka - angka, tetapi berupa kata - kata atau gambaran sesuatu disebut penelitian deskriptif. Penelitian deskriptif adalah penelitian yang dimaksudkan untuk menyelidiki keadaan, kondisi atau hal - hal lain yang sudah disebutkan, yang hasilnya dipaparkan dalam bentuk laporan penelitian. Oleh karena itu, penelitian ini merupakan penelitian deskriptif.

\section{HASIL PENELITIAN DAN PEMBAHASAN}

\section{Hasil Penelitian}

Bentuk Kesalahan Penggunaan Kata Baku pada Teks Laporan Hasil Observasi Siswa Kelas X MAN 2 Model Medan

Berdasarkan analisis penggunaan kata baku pada teks laporan hasil observasi terhadap 43 teks siswa kelas X MAN 2 Model Medan ,maka kesalahan penggunaan kata baku yang terdapat pada teks laporan hasil observasi siswaadalah sebagai berikut.

1. Sebanyak 43 karangan siswa terdapat 70 (18.6\%) kesalahan penggantian huruf, 23 teks dikategorikan sangat baik, 16 teks dikategorikan baik, dan 4 teks dikategorikan cukup.

2. Sebanyak 43 karangan siswa terdapat 46 (12.2\%) kesalahan penghilangan huruf, 31 teks dikategorikan sangat baik, 8 teks dikategorikan baik, 2 teks dikategorikan cukup, dan 2 teks dikategorikan sangat kurang.

3. Sebanyak 43 karangan siswa terdapat $23(6.1 \%)$ kesalahan penggunaan kata baku pada penyederhanaan huruf, 12 teks dikategorikan sangat baik, 10 teks dikategorikan baik, dan 6 teks dikategorikan sangat kurang.

4. Sebanyak 43 karangan siswa terdapat 223 (60\%) kesalahan penggunaan baku pada ejaan, 25 teks dikategorikan sangat baik, 14 teks dikategorikan baik, 3 teks dikategorikan cukup, dan 1 teks dikategorikan kurang. 
5. Sebanyak 43 karangan siswa terdapat 14 (3.7\%)kesalahan penggunaan kata baku pada pilihan kata, 33 teks dikategorikan sangat baik, 8 teks dikategorikan kurang, dan 2 teks dikategorikan sangat kurang.

\section{Pembahasan}

1. Bentuk Kesalahan Penggunaan Kata Baku pada Teks Laporan Hasil Observasi Siswa Kelas X MAN 2 Model Medan

Berdasarkan hasil temuan penulis di atas, maka kesalahaan penggunaan kata bakudalam teks laporan hasil observasi siswa kelas X MAN 2Model Medanakan di uraikan sebagai berikut.

1. Kesalahan Penggantian Huruf pada Teks Laporan Hasil Observasi

Kesalahan penggantian huruf yang ditemukan dalam teks laporan hasil observasi siswa kelas X MAN 2ModelMedan berjumlah 70 kesalahan.Kesalahan penggantian huruf yang dominan adalah pada penggunaan huruf vokal $(a, e$, dan $u)$ dan konsonan $(f$, $t, r, k$, dan $v$ ).Hal itu terjadi karena siswa belum paham akan penggunaan kata baku sesuai dengan tata bahasa baku.

2. Kesalahan Penghilangan Huruf pada Teks Laporan Hasil Observasi

Kesalahan penghilangan huruf yang ditemukan dalam teks laporan hasil observasi siswa kelas XMAN 2ModelMedan berjumlah 46 kesalahan. Kesalahan penghilangan huruf yang dominan adalah pada penggunaan huruf vokal $(e$ dan $i$ ) dan konsonan $(h, n, s, k$, dan $g)$. Hal itu terjadi karena siswa belum paham akan penggunaan kata baku sesuai dengan tata bahasa baku.

3. Kesalahan Penyederhanaan Huruf pada Teks Laporan Hasil Observasi

Kesalahan penyederhanaan huruf yang ditemukan dalam teks laporan hasil observasi siswa kelas X MAN 2ModelMedan berjumlah 23 kesalahan.Kesalahan penyederhanaan huruf yang dominan adalah pada penggunaan huruf vokal (au dan ai) dan konsonan $(k h)$.Hal itu terjadi karena siswa belum paham akan penggunaan kata baku sesuai dengan tata bahasa baku.

4. Kesalahan Ejaan pada Teks Laporan Hasil Observasi

Kesalahan ejaan yang ditemukan dalam teks laporan hasil observasi siswa kelas X MAN 2ModelMedan berjumlah 223 kesalahan . Kesalahan ejaan huruf yang dominan 
adalah pada pemisah dan penyatuan kata di.Hal itu terjadi karena siswa belum paham akan penempatan kata ejaan yang baik.

5. Kesalahan Pilihan Kata pada Teks Laporan Hasil Observasi

Kesalahan pilihan kata yang ditemukan dalam teks laporan hasil observasi siswa kelas X MAN 2Model Medan berjumlah 14 kesalahan . Kesalahan pilihan kata yang dominan adalah pengunaan kata kayak. Hal itu terjadi karena siswa belum paham akan penempatan pilihan kata yang tepat.

Berdasarkan pembahasan penelitian di atas, kesalahan penggunaan kata baku pada teks laporan hasil observasi dibedakan menjadi lima bagian, yaitu kesalahan penggantian huruf, penghilangan huruf, penyederhaaan huruf, ejaan, dan pilihan kata. Adapun jumlah kesalahan penggantian huruf sebesar $18,6 \%$, kesalahan penghilangan huruf sebesar $12,2 \%$, kesalahan penyederhanaan huruf sebesar $6.1 \%$, kesalahan ejaan sebesar $60 \%$, dan kesalahan pilihan kata sebesar $3.7 \%$.

Oleh sebab itu dapat diketahui bahwa kesalahan yang paling dominan yang ditemukan dalam karangan siswa kelas X MAN 2 Model Medan adalah penggunaan ejaan yang benar, siswa tidak memahami aspek ejaan (pemisahan atau penyatuan bagian kata dan kata penghubung.). Tentunya hal ini menunjukkan kurang pengetahuan siswa tentang aspek ejaan. Mayoritas siswa belum mengetahi kaidah penggunaan kata baku yang tepat. Siswa hanya mengandal pengetahuan tanpa mencari tahu atau membaca pedoman umum kata baku.

\section{Faktor Kesalahan Penggunaan Kata Baku pada Teks Laporan Hasil Observasi Siswa Kelas X MAN 2 Model Medan.}

Adapun kesalahan penggunaan kata baku pada teks laporan hasil observasi siswa kelas X MAN 2 Model Medan tentunya tidak terlepas dari faktor - faktor penyebabnya. Faktor penyebab kesalahan penggunaan kata baku adalah sebagai berikut.

1) Kurangnya perhatian siswa terhadap pembelajaran yang diberikan oleh guru

Saat proses pembelajaran guru telah mengajarkan kepada siswa aturan penggunaan kata baku secara tidak langsung. Hal ini tentunya dapat dilihat ketika guru memberikan materi pembelajaran dan menuliskannya ke papan tulis. Guru menuliskan materi sesuai dengan aturan tata bahasa baku yang berlaku namun masih banyak dijumpai kesalahan penggunaan kata baku dalam catatan siswa. Adapun kesalahan berikut, yaitu "karna", "fikiran", "kalo", dan lain - lain

2) Penggunaan kaidah kata baku yang kurang memadai 
Berdasarkan hasil wawancara peneliti dengan guru bidang studi Bahasa Indonesia MAN 2 Model Medan menyatakan bahwa kemampuan siswa masih rendah dalam penggunaan kata baku, hal ini terlihat dari hasil ujian mata pelajaran ejaan sesuai dengan kurikulum 2013 yang digunakan di MAN 2 Model Medan. Ada sebanyak 18 orang atau sekitar $45 \%$ siswa yang lulus dengan nilai rata - rata 75. Sedangkan sisanya 22 orang atau sekitar 55\% tidak mencapai standar kompetensi yang telah ditentukan dari sekolah yaitu 75. Adapun kesalahan siswa, yaitu pada penggunaan huruf dan aspek ejaan.

3) Kurangnya latihan menulis sesuai kaida kata baku

Kemampuan menulis yang baik serta merta membutuhkan waktu waktu yang singkat. Perlu adanya latihan berulang kali agar ulisan ataupun karangan menjadi baik dan benar. Kondisi tersebut tidak sejalan dengan aktivitas keseharian siswa baik di sekolah maupun di rumah. Mereka menulis mengungkapkan bahwa kegiatan menulis rata-rata sangat jarang dilakukan saat belajar disekolah karena waktu yang terbatas. Apabila menulis dilaksanakan di rumah, hal itu dikarenakantugas yang tidak selesai dikerjakan di sekolah kemudian harus diselesaikan di rumah. Kesadaran yang tumbuh dari pribadi masing-masing siswa kelas $\mathrm{X}$ MAN 2 Model Medan Pelayaran Buana Bahari untuk latihan menulis karangan dinilai masih kurang.

4) Siswa kurang teliti ketika membuat karangan

Kurang telitinya siswa dalam membuat karangan menjadi salah satu penyebab terjadinya kesalahan penggunaan kata baku. Kesalahan yang biasa terjadi karena ketidaktelitian, yaitu salah penulisan. Siswa cenderung ingin cepat selesai dalam mengerjakan tugas sehingga tidak memeriksa kembali apakah terdapat kesalahan penulisan dalam karangan atau tidak.banyak ditemukan kesalahan karena penggunaan fonem suatu kata. Siswa juga sering membuat kalimat panjang dan berlebihan hingga inti kalimatnya menjadi tidak jelas.

Sikap siswa yang tidak perduli siswa terhadap karangan yang mereka buat tersebut menjadikan karangan yang tidak sempurna. Mereka menganggap kesalahan yang mereka buat dalam karangan adalah kesalahan biasa. Padahal, kesalahan yang dilakukan siswa tersebut merupakan kesalahan yang fatal. Hal itu dikarenaka mereka tahu bahwa itu salah, namun mereka membiarkannya karena mengagggap kesalahan tersebut adalah kesalahan kecil.

\section{PENUTUP}


Berdasarkan hasil penelitian dan pembahasan mengenai analisis kesalahan penggunaan kata baku pada teks laporan hasil observasi siswa kelas X MAN 2 Model Medan Tahun Pembelajaran 2016/2017 dapat ditarik kesimpulan sebagai berikut. 1) Sebanyak 43 karangan siswa terdapat $70(18.6 \%)$ kesalahan penggantian huruf, 23 teks dikategorikan sangat baik, 16 teks dikategorikan baik, dan 4 teks dikategorikan cukup, 2) Sebanyak 43 karangan siswa terdapat $46(12.2 \%)$ kesalahan penghilangan huruf, 31 teks dikategorikan sangat baik, 8 teks dikategorikan baik, 2 teks dikategorikan cukup, dan 2 teks dikategorikan sangat kurang, 3) Sebanyak 43 karangan siswa terdapat 23 (6.1\%)kesalahan penggunaan kata baku pada penyederhanaan huruf, 12 teks dikategorikan sangat baik, 10 teks dikategorikan baik, dan 6 teks dikategorikan sangat kurang, 4) Sebanyak 43 karangan siswa terdapat 223 (60\%) kesalahan penggunaan baku pada ejaan, 25 teks dikategorikan sangat baik, 14 teks dikategorikan baik, 3 teks dikategorikan cukup, dan 1 teks dikategorikan kurang, 5) Sebanyak 43 karangan siswa terdapat 14 (3.7\%)kesalahan penggunaan kata baku pada pilihan kata, 33 teks dikategorikan sangat baik, 8 teks dikategorikan kurang, dan 2 teks dikategorikan sangat kurang.

\section{DAFTAR PUSTAKA}

Arifa, Fita Nur. 2016. Pedoman Kata Baku dan Tidak Baku Dilengkapi Pedoman Umum Pembentukan Istilah dan Ejaan Bahasa Indonesia (EBI).Yogyakarta :Aksara Sudaryanto. 2015.Metode dan Aneka Teknik Analisis Bahasa. Yogyakarta: Duta Wacana University.

Miftahuddin, Ade. 2014. AnalisisKesalahanPenggunaan Kata Baku dalam PembelajaranMenulisLaporanPerjalanSiswaKelas VII SMP Al- Hidayah

LebakBulus Jakarta.Skripsi, FKIP. UIN Syarif Hidayatullah, Jakarta.

Widianingsih, RetnoKurniasari. 2014. AnalisisKesalahanEjaanPadaBuku Teks Mata Pelajaran Bahasa Indonesia Untuk Kelas VI SekolahDasarTerbitan Yudhistira Dan Erlangga.Skripsi, FBS, Universitas Negeri Yogyakarta, Yogyakarta. 